\title{
AN EFFECT OF BIODIESEL (B20) ON LIFE TIME LOCOMOTIVE FUEL FILTER
}

\section{PENGARUH BIODIESEL (B20) PADA UMUR PAKAI FILTER BAHAN BAKAR LOKOMOTIF}

\author{
Muhammad Ma'ruf a, Ihwan Haryono a \\ a The Centre for Thermodynamics, Engines and Propulsion System \\ The Agency for the Assessment and Application of Technology \\ Bd 230, the Centre for Science, Research, and Technologies, South Tangerang \\ Tel: +62217560539, Fax: +62217560538 \\ e-mail : muhammad.maruf@bppt.go.id, ihwan.haryono@bppt.go.id
}

\begin{abstract}
The effect of using B20 palm oil biodiesel on rail locomotive fuel filters was evaluated in this study. The generator water separator filter, generator main filter and locomotive drive filter after being used along the filter replacement period were analysed in laboratories and compared with new ones as reference. The analysis was using SEM/EDS, FTIR and GC. The FTIR and GC test results show that the fuel filter has a number of deposits from the components of biodiesel fuel, that are diesel and biodiesel. However, morphological test results using SEM show that the filter surface has not been completely covered by liquid and fuel deposits. The results of the tests and analysis indicated that the usage of 125 hours (for locomotive genset) and 3 months for locomotive drive engine with $20 \%$ palm biodiesel fuel can still guarantee the filtration to maintain the performance and prevent damage to fuel and engine system components.
\end{abstract}

Keywords : palm biodiesel; fuel filter; locomotive; SEM/EDS; FTIR; glycerides

\begin{abstract}
Abstrak
Efek penggunaan biodiesel minyak sawit B20 pada filter bahan bakar lokomotif kereta api dievaluasi dalam penelitian ini. Filter pemisah air generator, filter utama generator, dan filter penggerak lokomotif setelah digunakan selama periode umur penggantian filter dianalisa di laboratorium dan dibandingkan dengan yang baru sebagai referensi. Analisis menggunakan SEM/EDS, FTIR dan GC. Hasil uji FTIR dan GC menunjukkan bahwa filter bahan bakar memiliki sejumlah deposit dari komponen bahan bakar biodiesel, yaitu diesel dan biodiesel. Namun, hasil uji morfologis menggunakan SEM menunjukkan bahwa permukaan filter belum sepenuhnya tertutup oleh deposit cairan dan bahan bakar. Hasil pengujian dan analisis menunjukkan bahwa penggunaan 125 jam (untuk lokomotif genset) dan 3 bulan untuk mesin penggerak lokomotif dengan $20 \%$ bahan bakar biodiesel sawit masih dapat menjamin filtrasi untuk mempertahankan kinerja dan mencegah kerusakan bahan bakar dan komponen sistem mesin.
\end{abstract}

Kata kunci : biodiesel sawit; filter bahan bakar; lokomotif; SEM/EDS; FTIR; gliserida

Diterima (received ) : 24 Oktober 2019 , Direvisi (revised) : 08 November 2019,

Disetujui (accepted) : 18 November 2019

\section{INTRODUCTION}

The use of biodiesel fuel can potentially to change the fuel filter change interval. Various studies show the formation of deposits which can cause a blockage of a filter due to the presence of alkali metals, sodium and potassium located in biodiesel 1). Products that have the potential to contaminate the use of biodiesel may result from fatty acid 
glyceride during storage and during the oxidation process of biodiesel which may cause oligomers and low molecular weight aliphatic compositions ${ }^{2)}$.

The use of biodiesel can also increase the water content derived from contaminants that can cause precipitation, reduce the lubricity and media for the growth of microorganisms that can damage the fuel system 3,4). In addition to these contaminants, saturated mono-glycerides, sterol glucosides and carboxylic acids are the main contaminants that affect the blockage of fuel filters whose levels depend on the raw materials used 5,6 ). The potential will increase when using a high fuel injection pressure system (above 1000 bar). This is because the fuel filter for high pressure technology is smaller porosity to prevent wear on injection system components that have very small clearance compared to technology of conventional/low pressure injection system ${ }^{7)}$. Similarly, in high-pressure injection systems, high temperatures from injection system returns can lead to thermal oxidation. This high temperature return fuel when in contact with the metal from the fuel tank causes the emergence of oxidizing products such as aldehydes and carboxylic acids which can create corrosion on the metal part of the fuel injector system ${ }^{8)}$. In addition to this the potential for polymerization is also a source of plugging in fuel filters ${ }^{9}$ ). Thus, the use of biodiesel to be used must have strict property or handling standards to avoid problems in the use of high-risk biodiesel.

Through the government's decision that the utilization of diesel engine fuel in Indonesia should contain $20 \%$ biodiesel, the utilization of $20 \%$ biodiesel (B20) fuel for locomotive engine at state-owned train company, (PT. KAI), started in early January 2016. The biodiesel fuel that has been marketed in Indonesia is a mixture of solar (diesel) and biodiesel from oil palm oil (FAME) that meets the established national standards ${ }^{10)}$. With the passage of time after the utilization of B20, the facts in the field found several problems related to the fuel system such as cracking and breaking of the tip nozzle on the CC 205 and CC 206 locomotive injectors ${ }^{11)}$. Similarly, the frequency of fuel filter changes was increasing drastically ${ }^{12)}$. According to a person who in charge in maintenance, the filter replacement time decreased to 125 hours for locomotive generator filter and 3 months for locomotive filter. The replacement time was approximately $50 \%$ shorter than the previous replacement time when using diesel fuel containing biodiesel around $10 \%$.
In order to identify and evaluate the problem of B20 fuel utilization in PT. KAI, The Ministry of Energy and Mineral Resources the department of resources and energy as a government institution formed teams that responsible for conducting studies to obtain technical data in answering the problems as mentioned above and provide recommendations for solutions. The teams were divided into 3 sub-teams that were tasked the study through several approaches. The third sub-team was in charge of investigating and reviewing the fuel components systems for the locomotives and gensets. The team was working from early April to the end of June 2017. Fuel filter samples were taken at two locomotive depots in Jakarta in April at the time of filter removal during the maintenance period. So that the condition of the filter sample was the current condition during the one maintenance period.

The locomotive power system in PT. KAI was used two system engine that was on genset to supply electric train and engine for drive locomotive. In the genset engine, fuel filtration system uses two levels of filtration, namely water separator and main filter. The other one was a filter for locomotive engine. For one maintenance period, the time replacement was 125 hours for genset water separator and 3 months for filter of the locomotive. The replacement time was determined after experiencing filter blockage issues due to B20 usage.

In this study, an investigation was done for samples of locomotive filter and water separator used after one periodic maintenance, which was 3 months for locomotive filters and 125 hours for water separators. The aim was to evaluate the effect of using B20 on the conditions and filtering ability of the filter and water separators.

\section{MATERIALS AND METHODS}

\section{Sampling and preparation}

Test samples taken from two locomotive depots of the state-owned train company, PT. KAI, consist of six samples of filter that were genset water separator, genset main filter and locomotive filter which paired with condition of former with new condition respectively. The condition of the samples was after operating with the use of $20 \%$ palm oil biodiesel (B20). 
The sample filters as seen in Fig. 1 were taken:

From the locomotive depot in Jatinegara:

1. Locomotive filter (used)

2. Locomotive filter (new)

From the locomotive depot Central Jakarta:

1. Genset water separator (used)

2. Genset water separator (new)

3. Genset main filter (used)

4. Genset main filter (new)

The testing of the sample under the new conditions was intended as a comparison so that the source of the contaminant materials was detected. The undetectable material on the new sample that presented in the used sample filter identified as the contaminants.

For the record, for genset fuel filter (used) was Deutze ${ }^{\mathrm{TM}}$ product, while filter (new) is a product of Volvo ${ }^{\mathrm{TM}}$.
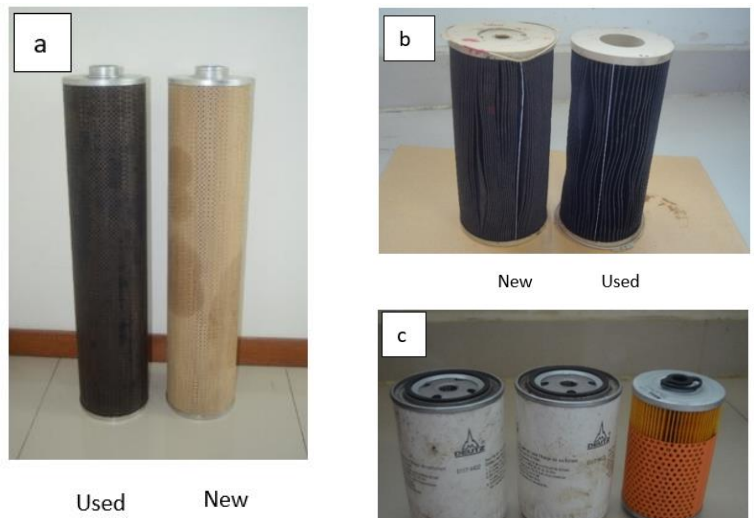

New Used

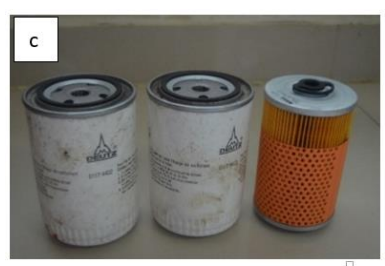

Used

New

Figure 1.

The sample filters

a. Used and new filters for locomotives b. New and used water separator

c. New and used filter (with casing) for the generator

The condition of the entire surface of the filter sample was the same (uniform) that was black for water separator, either for the new and the used genset water separator. Black colour on the entire surface sample filter occurred on the used sample filter, both for genset main filter and the locomotive engine.

Sampling for SEM/EDS and FTIR test was done by cutting filter paper (new and used) with size $2-3 \mathrm{~cm} \times 5-15 \mathrm{~cm}$ which then sent to the accredited laboratory for conducting tests. Sampling for GC test was done by cutting filter paper with size $2 \mathrm{~cm} \times 15 \mathrm{~cm}$ (Figure 2). Furthermore, the pieces sample paper was extracted using ultrasonic bath for 15 minutes in $100 \mathrm{ml}$ solvent thf (tetra hydro furant). The extraction results were stored in a bottle for the night. The extraction from the sample was sent to the other accredited laboratory for conducting test the content of mono-, diand triglyceride.
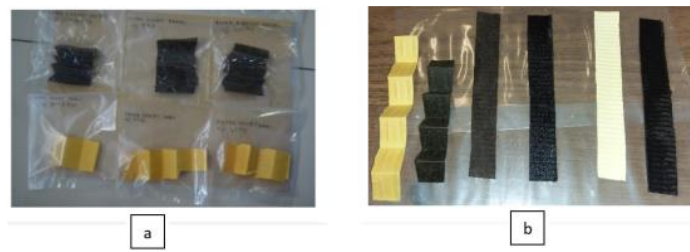

Figure 2.

Pieces of filter paper for analysis:

a. For SEM/EDS \& FTIR and b. for GC.

\section{Morphological Analysis of Surface Filters and Elements of Compilers with SEM- EDS}

The morphology of the fuel filter surface was analysed by using Scanning Electron Microscopy (SEM) and its constituent elements using Energy Dispersive Spectroscopy (EDS). Testing equipment used was JEOL JSM-6510LA by using ASTM E 1508-13 test standard. Testing was done with the parameters and test conditions as follows:

Preparation: The sample was heated with $60^{\circ} \mathrm{C}$ oven for 20 hours for a secondhand filter, followed by coating with gold $\mathrm{Au}$ ) $40 \mathrm{~mA}$.

Analysis: Electron Voltage $20 \mathrm{kV}$ with 100x magnification. The analysis was done $3 x$ with different location for each sample.

\section{Analysis of Functional Groups with FTIR}

The functional group analysis was performed to determine the possibility of the compounds present in the filter. The analysis was done by using FTIR Tensor 27 with Hyperion spectrophotometer in the laboratory of Centre for Polymer Technology (STP-BPPT). The process of analysing the sample was done without preparation process and tested by Attenuated Total Reflection (ATR) method. Test method used in accordance with ASTM E 1252-13 standard.

\section{Glyceride Analysis with GC}

Glyceride analysis was performed using standard method EN 14015. 


\section{RESULTS AND DISCUSSIONS}

\section{Filter Analysis with SEM \& EDS}

The SEM test results for locomotive filter are shown in Figure 3. From the pictures, there is a difference of texture/morphology of the surface of the used locomotive filter when compared to the new one. The fibres of the used filter look uneven as the new filter and partially closed by the layer. Allegedly the coating is derived from diesel oil/biodiesel or other contaminants. The allegations will be strengthened by the tests using FTIR and GC.

Visually, from the SEM image (Figure 4), it appears that both new and used water separator are seen as a morphology like layers between the fibres. For used filters, at the $1^{\text {st }}$ and $3^{\text {rd }}$ shots it is seen that the filter fibres appear to be more covered by the substrate comparing to the new water separator filter in wet conditions. Figure 5 show that both new and used water separator filters are contaminated with biodiesel fuel.

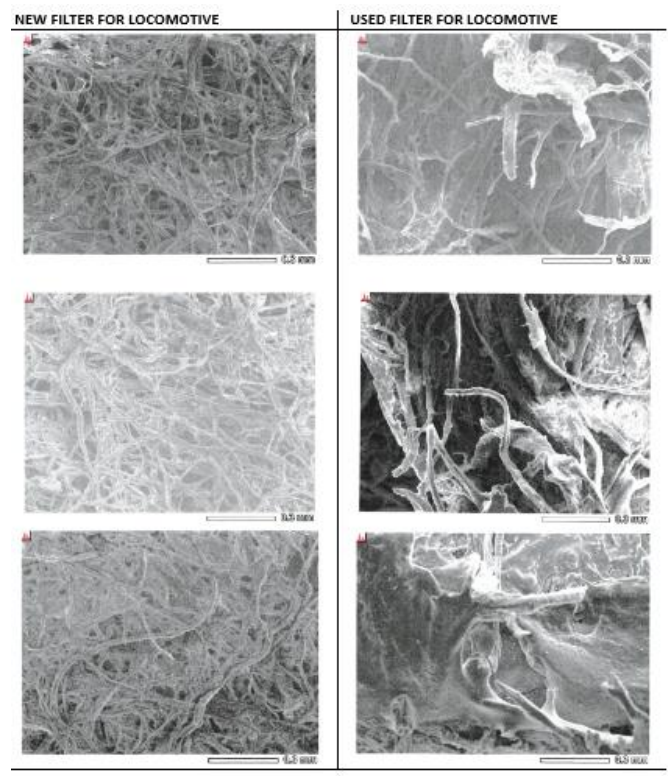

Figure 3.

SEM new and used locomotive filters with $100 x$ magnification at 3 different shooting locations.

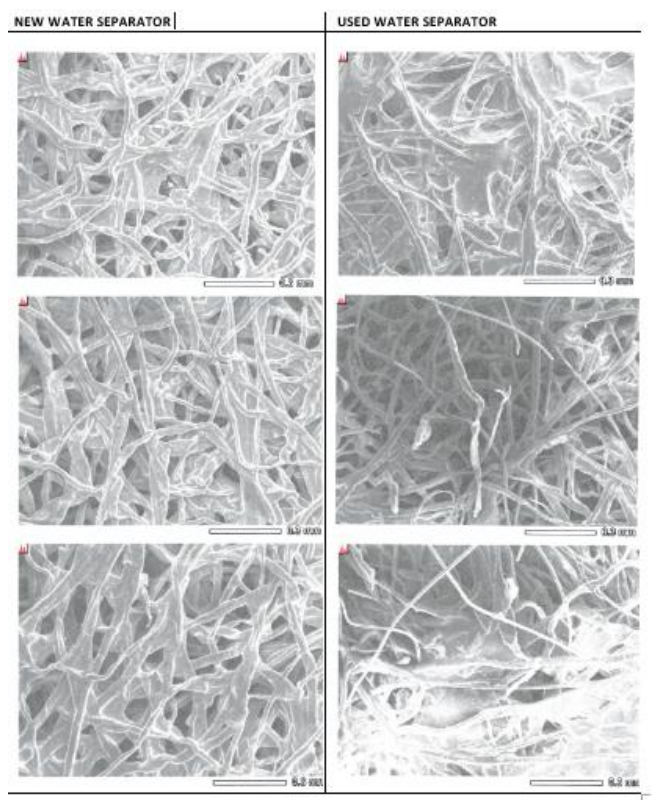

Figure 4.

SEM filter new and used water separator with 100x magnification at 3 different shooting locations.

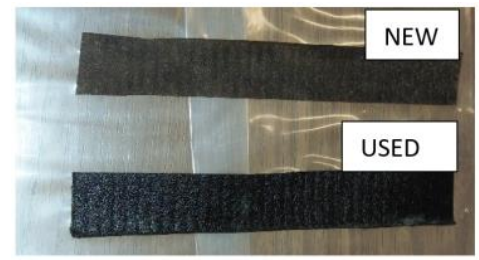

Figure 5.

Visual appearance of new and used water separator filters.

The result of SEM analysis of the new genset filter and used genset filter, as seen in Figure 6, do not show any significant difference, it is possibly because in addition to the relatively early age (about 125 hours). The fuel through to this filter has passed from the water separator filter so that some impurities have been filtered out. 


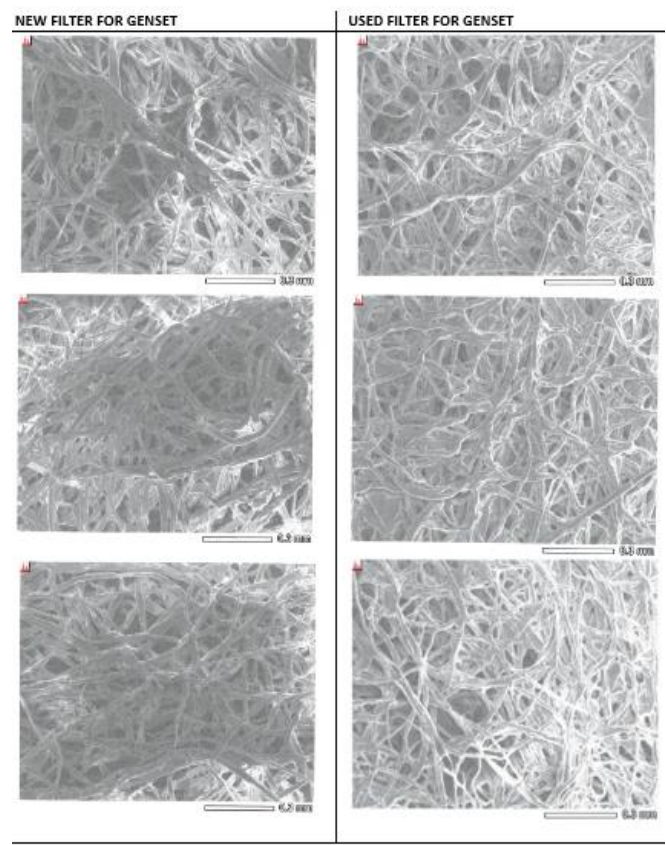

Figure 6.

SEM new and used filters on genset with $100 x$ magnification at 3 different shooting locations.

EDS analysis was done to the filter to know the constituent elements of the existing components in the filters. Measurements were made on the used filters and the new filters for comparison.

The results are shown in Table 1.

Table 1.

Result of filter component analysis and its contaminants by using EDS

\begin{tabular}{|c|c|c|c|c|c|c|c|}
\hline \multirow[b]{2}{*}{$\begin{array}{l}\frac{\vec{\sigma}}{\Phi} \\
\frac{E}{\Phi} \\
\frac{\Phi}{\Psi}\end{array}$} & \multirow[b]{2}{*}{ 壱 } & \multicolumn{6}{|c|}{ Samples } \\
\hline & & 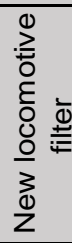 & 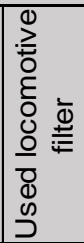 & 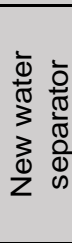 & 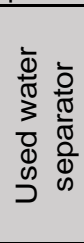 & 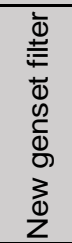 & 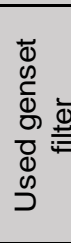 \\
\hline$C$ & $\% m$ & 46.64 & 77.25 & 76.63 & 77.4 & 51.55 & 76.71 \\
\hline 0 & $\% m$ & 52.47 & 21.21 & 23.37 & 21.53 & 48.34 & 23.29 \\
\hline $\mathrm{Al}$ & $\% m$ & 0.89 & 0.47 & - & $0.20^{* \star}$ & $0.10^{* *}$ & - \\
\hline $\mathrm{Si}$ & $\% m$ & - & - & - & 0.46 & - & - \\
\hline$S$ & $\% m$ & - & $0.3^{* * *}$ & - & $0.11^{* *}$ & - & - \\
\hline $\mathrm{Ca}$ & $\% m$ & - & 0.77 & - & $0.31^{* * *}$ & - & - \\
\hline
\end{tabular}

Note: The values in the table are the average values of 3 times the measurements in three different areas.

${ }^{* *}$ ) is the value of 3 measurements and is only found in 1 location.

$\left.{ }^{* * *}\right)$ is the average of 3 measurements and is only found in 2 locations.
From the Table 1 show that on the locomotive filter:

a. Elements of carbon, oxygen and aluminium are the constituents of the filter material used.

b. The carbon element is also a major component of the residue in the used locomotive filter seen from the increase in the percentage of mass when compared with the results of the new filter.

c. In the locomotive filter found that the impurities are the element of sulphur and calcium. The findings of impurities show that locomotive filters are capable of reducing the impurities $S$ and $\mathrm{Ca}$ present in the fuel before entering the combustion chamber. Sulphur may be derived from diesel fuel. Sulphur is an element which is soluble in fuel and therefore easily passes filter paper and only a small amount is captured on the filter. Therefore the sulphur reduction should go through desulfurization rather than filtration. Calcium most likely as an inorganic compound is probably derived from fuel additives or catalysts, generally crystals so that they are easily retained in the filter.

The result of new and used water separator filter analysis:

a. Some impurities found in the used water separator filter include $\mathrm{Al}, \mathrm{Si}, \mathrm{S}$ and $\mathrm{Ca}$.

b. Both carbon and oxygen elements are found in both new and used filters, the presence of compounds composed of carbon and oxygen elements is confirmed by FTIR.

Result of new and used genset filter analysis:

a. No metal impurities found in used genset filters are possible because some metal impurities have been filtered in the water separator.

b. The carbon and oxygen elements may be derived from the filter material as well as from the residue on the used filters. The oxygen component is also derived from biodiesel which is an oxygenate biofuel. To ensure the presence of carbonoxygen compounds are confirmed by FTIR. 


\section{Filter Analysis with $\quad$ FTIR Spectrophotometer}

Confirmation the presence of diesel \& biodiesel oils in filters through the FTIR spectra (Figure 7) is characterized by absorption of several wave numbers including: biodiesel ester uptake $(C=O)$ at wave number $1745 \mathrm{~cm}^{-}$ ${ }^{1}$, uptake of clusters - $\mathrm{CH} 2$ - and - $\mathrm{CH} 3$ - apparent at wave numbers 2924, 2854, 1462 and 1376 which can be derived from alkyl chains of biodiesel and alkanes from diesel oil ${ }^{13)}$.

Absorption peak for new and used locomotive filter has some 2 different phenomena. İt was quite different with Figure 8 and 9 which showed similar trend between new and used filter. At new filter of $1104 \mathrm{~cm}^{-1}$ and $3344 \mathrm{~cm}^{-1}$ were not appear at used filter. In the FTIR analysis using the sampling process Attenuated Total Reflection (ATR) method so that the wave absorption of the filter paper does not appear on the used filter. This is due to the substrate/deposit covered filter paper.

FTIR spectra of used water separator filter (Figure 8) indicate some compounds that can be derived from biodiesel and diesel oil. The fairly wide absorption around $3358 \mathrm{~cm}^{-1}$ is a characteristic absorption for the $-\mathrm{OH}$ group, this functional group probably derived from carboxylic acid, glycerides, glycerol or water. Carboxylic acid is an acid compound in biodiesel or better known as Total Acid Number whose number can increase with the age of biodiesel which is one of biodiesel degradation product. Another possibility is the presence of glyceride compounds (monoglycerides, diglycerides and triglycerides) that can be derived from biodiesel as a result of imperfect biodiesel production processes. The presence of these compounds will be further confirmed by using gas chromatography.

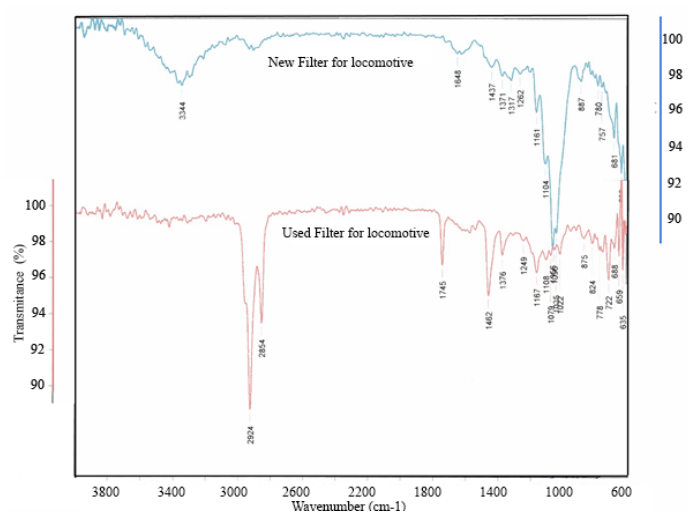

Figure 7.

FTIR spectra for locomotive filter.

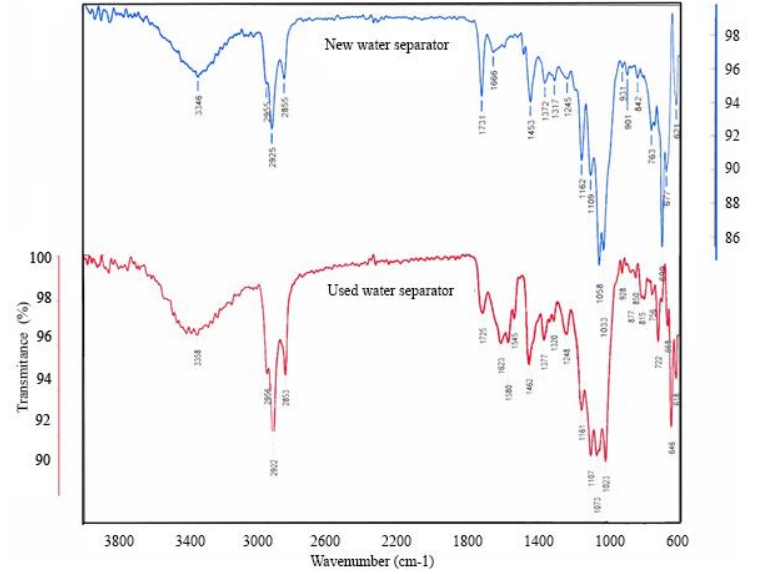

Figure 8.

FTIR spectra for water separator filter.

The characteristic absorption of the biodiesel ester group appears in the new filter at the wave number $1731 \mathrm{~cm}^{-1}$, this is because the new filter is contaminated during sample delivery where the condition is wet by biodiesel fuel. While in the filter the former $\mathrm{C}=\mathrm{O}$ absorption group slightly shifts to the wave number $1725 \mathrm{~cm}^{-1}$ which can be identified as the functional group of carboxylic acid, aldehyde or ketone which are biodiesel degradation compounds. The $\mathrm{CH} 2$ - and - $\mathrm{CH} 3$ functional groups may be derived from the alkyl chain of biodiesel as well as the diesel fuel alkane chain indicated by absorption at wave numbers 2956, 2922, 2853 and $1377 \mathrm{~cm}^{-1}$.

The absorption of the $\mathrm{C}=\mathrm{O}$ functional group is seen in the wave number $1745 \mathrm{~cm}^{-1}$ which is more directed to the functional group of the biodiesel ester, unlike the water separator filter in the preceding Figure 9 which further leads to the $\mathrm{C}=$ aldehyde, carboxylic and ketone groups derived from compound result of biodiesel degradation, so it can be concluded that existing biodiesel in genset filter condition is still better when compared with biodiesel left in water separator. The wide absorption around 3356 $\mathrm{cm}^{-1}$ is a stretching $-\mathrm{OH}$ group which is most likely to be derived from glycerol, glycerides or carboxylic acids. The existence of glyceride is proved by using Gas Chromatography. The presence of diesel and biodiesel can be inferred by the absorption of the wave number 2924, 2855 which is the absorption of the group - $\mathrm{CH} 2-$ \& $-\mathrm{CH} 3$, and the uptake of 1459 and 1373 showing the presence of $\mathrm{CH} 3$ groups. 


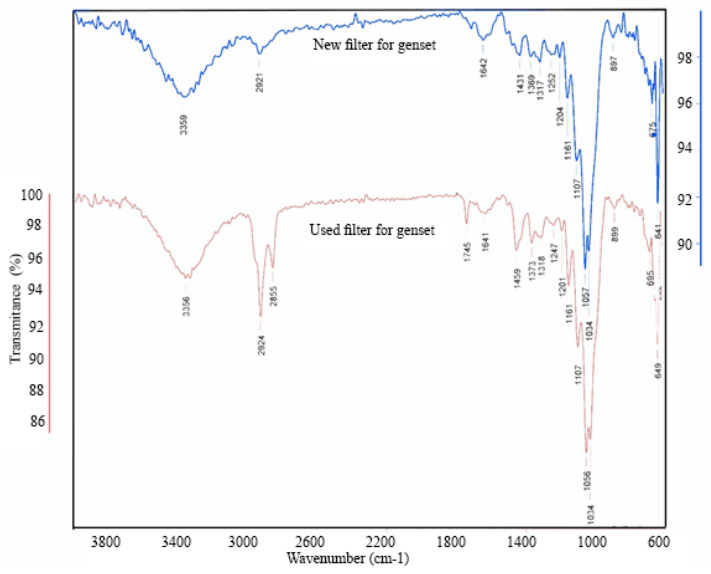

Figure 9.

FTIR spectra for genset filter.

\section{Filter Analysis with GC}

Gas Chromatography analysis using EN14015 method was done to confirm the presence of glyceride compounds either mono, di- or triglyceride. Analysis results are presented in the following Table 2.

Table 2.

Results of glycerides analysis

\begin{tabular}{|c|c|c|c|c|c|}
\hline z & 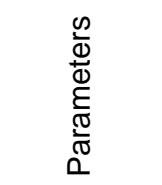 & 䓂 & 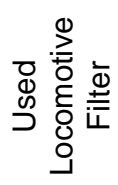 & 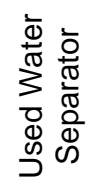 & 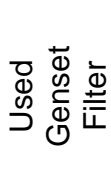 \\
\hline 1 & $\begin{array}{l}\text { Mono- } \\
\text { glycerides }\end{array}$ & $\% \mathrm{~m}$ & 0.015 & 0.017 & 0.012 \\
\hline 2 & $\begin{array}{c}\text { Di- } \\
\text { glycerides }\end{array}$ & $\% m$ & 0.004 & 0.004 & 0.004 \\
\hline 3 & $\begin{array}{c}\text { Tri- } \\
\text { glycerides }\end{array}$ & $\% m$ & 0.003 & 0.004 & 0.003 \\
\hline
\end{tabular}

Monoglyceride, diglyceride and triglyceride are found in used filters. This indicates that the filter serves to filter impurities from the results of the imperfect biodiesel manufacturing process.

Table 2 show the content of mono-, di-, and triglycerides which spread with almost the same concentration in all used filters. Monoglyceride concentration is more than five times compared to the others. While the diglyceride content is proportional to the triglyceride content. This monoglyceride content is suspected as a trigger the process of deposit formation in the biodiesel fuel filter faster than diesel oil. Biodiesel containing monoglyceride with certain levels can cause precipitation above the value of cloud point and potentially be the cause of filter blocking ${ }^{14)}$. Total glycerides can accumulate on the filter. The presence of water and sediment contaminants in the biodiesel fuel caught on the filter can attract glycerides and accumulate on the filter so that it can cause filters blocking 15). Determination of the decrease in filtration function needs to be done other tests such as pressure drop test and flow reduction. In addition to be able to filters blocking, mono, and triglycerides may also cause damage to injection systems, pistons, valves and other non-ferrous metals 16). Thus, the value of mono-, di- and triglyceride contents should be limited according to the specified standard.

\section{CONCLUSION}

The filter for generator system on the locomotive that fuelled by biodiesel $20 \%$ (B20) with the usage of about 125 hours and 3 months for the drive locomotive filter, from the surface morphology of the filter shows that the pores have not been completely covered by the residues and the content of metal impurities as well as glycerides. The presence of some metals and sulphur impurities in locomotive and used water separator filters, indicating the filter is capable of resisting or reducing glycerides and some other impurities that should not enter the fuel injection system. Derived elements from B20 were found in only a few of the entire observed areas. This indicate that the filter was still functioning properly and can be extended for a longer replacement life.

\section{Acknowledgements}

Authors may acknowledge to EBTKE, BPDPKS, PT. KAI, APROBI and any other persons or institutions that supported to any part of study.

\section{References}

1. Barker, J., Cook, S., and Richards, P., Sodium contamination of Diesel Fuel, its Interaction with Fuel Additives and the Resultant Effects on Filter Plugging and Injector Fouling. SAE paper. 2013-012687.

2. Jain, S. and Sharma, M.P., Stability of biodiesel and its blends: A review. 2010, 14, 667-678. 
3. Yang, C.T., Lee, S., Larsen, S., and Madsen, M., ULSD/Biodiesel blend and its effect on fuel/water separation. American Filtration \& Separation Society Annual Conference, May 19-22 (2008), Valley Forge, PA.

4. Fifth Edition Worldwide Fuel Charter ACEA. September 2013. ACEA, Alliance, EMA or JAMA websites.

5. Winston-Galant, M., Salley, S., Ng, K., and Dingle, P., Temperature Effect on Performance of a Commercial Fuel Filter for Biodiesel Blends with ULSD, SAE Technical Paper 2010-01-0473.

6. Fersner, A., and Galante-Fox, J., Biodiesel Feedstock and Contaminant Contributions to Diesel Fuel Filter Blocking, SAE Int. J. Fuels Lubr. 7(3):783-791, 2014.

7. Tang, T., Ku, Y., and Chen, C., Impacts of Biodiesel Blends on Fuel Filters of High Pressure Common Rail (HPCR) System, SAE Technical Paper 2016-01-1280, 2016

8. Zuleta, E.C., Baena, L., Rios, L.A., and Calderón, J.A., The oxidative stability of biodiesel and its impact on the deterioration of metallic and polymeric materials: a review. Dec. 2012. Journal of the Brazilian Chemical Society. vol.23 no.12.

9. Gopalan, K., Smith, C.R., Pickering, S.G., Chuck, C.J., and Bannister, C.D., Factors affecting diesel fuel degradation using a bespoke, high pressure, fuel system rig. 2017.

10. Standar Nasional Indonesia, SNI 7182:2015. Biodiesel.
11. Prakoso, R., ESDM Uji Coba Penerapan B20 di Kereta Api. Berita Satu, https://www.beritasatu.com/ekonomi/492 996/esdm-uji-coba-penerapan-b20-dikereta-api, diakses 18 Mei 2018.

12. Afriyadi, A.D., Pakai Biodiesel 20\%, Waktu Perawatan Pembangkit Jadi 3 Bulan. Detik Finance, https://finance.detik.com/energi/d4230500/pakai-biodiesel-20-waktuperawatan-pembangkit-jadi-3-bulan, diakses 26 Sep 2018.

13. Fang, H.L., and McCormick R.L. Spectroscopic Study of Biodiesel Degradation Pathways. SAE paper. 2006. 2006-01-3300.

14. Chupka, G.M., Fouts, L., Lennon, J.A., Alleman, T.L., Daniels, D.A., and McCormick, R.L. Saturated monoglyceride effects on lowtemperature performance of biodiesel blends. Fuel Processing Technology 118 (2014) 302-309.

15. Groschen, R., et.al. Petroleum Diesel Fuel and Biodiesel Technical Cold Weather Issues. 2009. Report to the Legislature. The Minnesota Department of Agriculture.

16. Ezquerro, A., et.al. Overcoming non technological barriers for full-scale use of Biodiesel in Europe. 2007. Final Publishable Report. Pro-Biodiesel and Intelligent Energy - Europe (IEE), http://www.probiodiesel.com/, accessed on October 09, 2019. 